\title{
Preparation and structure elucidation of alginate oligosaccharides degraded by alginate lyase from Vibro sp. 510
}

\author{
Zhenqing Zhang, ${ }^{\mathrm{a}}$ Guangli $\mathrm{Yu},{ }^{\mathrm{a}, *}$ Huashi Guan, ${ }^{\mathrm{a}} \mathrm{Xia}$ Zhao, ${ }^{\mathrm{a}}$ Yuguo Du${ }^{\mathrm{b}, *}$ \\ and Xiaolu Jiang ${ }^{\mathrm{c}}$ \\ ${ }^{a}$ Institute of Marine Drug and Food, Ocean University of China, Qingdao 266003, China \\ ${ }^{\mathrm{b}}$ Research Center for Eco-Environmental Sciences, Chinese Academy of Sciences, Beijing 100085, China \\ ${ }^{\mathrm{c}}$ Department of Food Science and Technology, Ocean University of China, Qingdao 266003, China
}

Received 17 December 2003; accepted 15 March 2004

\begin{abstract}
Alginate that was purified from the fermentation solution of marine bacteria Vibro sp. 510 under specific reaction conditions was hydrolyzed by alginate lyase. Seven oligosaccharides, including di-, tri- and tetrasaccharides, were isolated through low-pressure, gel-permeation chromatography (LP-GPC) and semipreparative strong-anion exchange (SAX) fast-protein liquid chromatography (FPLC). The oligosaccharide structures were elucidated based on ESIMS and 2D NMR spectral analysis. The hydrolytic specificity of this alginate lyase to alginate is discussed.
\end{abstract}

(C) 2004 Elsevier Ltd. All rights reserved.

Keywords: Alginate lyase; Guluronic acid; Mannuronic acid; Alginate; Oligosaccharides

\section{Introduction}

Alginate, a water-soluble linear polymer from brown algae, is composed of $(1 \rightarrow 4)$ - $\beta$-D-mannuronic acid $(\mathrm{M})$ and $\alpha$-L-guluronic acid $(\mathrm{G})$ units in the form of a homopolymeric (MM- or GG-blocks) and heteropolymeric sequences (MG- or GM-blocks). ${ }^{1,2}$ Owning to its gelling ability, stabilizing properties and high viscosity, alginate and derivatives are widely used in the food, cosmetics and pharmaceutical industries. ${ }^{3,4}$ Recent studies have revealed that alginate hydrolysates and their derivatives exhibit many important bioactivities, such as stimulating human keratinocytes, ${ }^{5}$ accelerating plant root growth ${ }^{6}$ and enhancing penicillin production from cultures of Penicillium chrysogenum. ${ }^{7}$ Enzymatically depolymerized alginate oligosaccharides can cause cytotoxic cytokine production in human mononuclear cells. ${ }^{8}$ PSS (propylene glycol alginate sulfate sodium)

\footnotetext{
* Corresponding authors. Tel.: +86-532-2031560; fax: +86-532-2033054; e-mail addresses: glyu@mail.ouc.edu.cn; duyuguo@ mail.rcees.ac.cn
}

and PGMS (propylene glycol mannuronate sulfate), which are two kinds of low-molecular-weight alginate derivatives, showed antioxidation and prevention of cardiovascular and cerebrovascular diseases. ${ }^{9,10}$

A number of alginate lyases from decayed brown algae, mollusks and bacteria have been described. ${ }^{11,12}$ These lyases usually hydrolyze alginate by $\beta$-elimination, and the mechanism is similar to that of alkaline degradation to glycuronans. ${ }^{13,14}$ Technically, gel-permeation chromatography, strong-anion exchange chromatography, ESIMS and 2D NMR spectral analysis have been successfully used in the sequential structure determination of alginate-derived oligosaccharides. ${ }^{15-21}$ In this paper, we use extracellular endoalginate lyase from Vibro sp. 510 to hydrolyze alginate, and the oligosaccharide fractions were separated on BioGel P4 column. The uniform-sized oligosaccharides with different $\mathrm{M} / \mathrm{G}$ ratios were further isolated by SAX-FPLC, and seven alginate-derived oligosaccharides, namely $\Delta \mathrm{G}, \Delta \mathrm{GG}, \Delta \mathrm{MG}, \Delta \mathrm{GGG}, \Delta \mathrm{MGG}, \Delta \mathrm{GMG}$ and $\Delta \mathrm{MMM}$, were obtained. ${ }^{10,15,22}$ All the structures were elucidated using ESIMS, ${ }^{1} \mathrm{H},{ }^{13} \mathrm{C}$ NMR,${ }^{1} \mathrm{H}-{ }^{1} \mathrm{H}$ COSY, HMQC and HMBC techniques. 


\section{Results and discussion}

The alginate was hydrolyzed by alginate lyase of Vibro sp. 510 for $24 \mathrm{~h}$, and a higher-molecular-weight component was precipitated by adding ethanol to the extracts. The supernatant containing alginate-derived oligosaccharides (account for $\sim 28 \%$ ) was evaporated off and separated on a BioGel P4 column. The separation profile (Fig. 1) of the oligosaccharides showed four major fractions based on UV absorption and uronic acid analysis, marked as Fr I, Fr II, Fr III and Fr IV in yields of $40 \%, 45 \%, 13 \%$ and $2 \%$, respectively. ESIMS gave $352.5,528.5,704.8$ and 881.2 corresponding to $\mathrm{Fr}$ I, Fr II, Fr III and Fr IV (Table 1), indicating di-, tri-, tetra- and pentasaccharide fragments, respectively.

The uniform sized fractions of Fr I, Fr II and Fr III were further separated by SAX-FPLC. Fr I showed one symmetric peak (compound 1), but Fr II and Fr III showed two (compounds $\mathbf{2}$ and $\mathbf{3}$ ) and four (compounds 4-7) peaks. Each fraction was then purified by semipreparative SAX-FPLC using a gradient elution program. Seven pure oligosaccharides (compounds 1-7) were thus obtained. Their precise structures were further determined from their 2D NMR spectra. The structure of Fr IV was not established due to the limited amount of this sample.

Through ${ }^{1} \mathrm{H}-{ }^{1} \mathrm{H}$ COSY and $\mathrm{HMQC}$ analysis, all proton and carbon signals of $\mathbf{1}$ can be assigned. The chemical shifts of $\mathrm{H}-4^{\mathrm{II}} \quad(5.92 \mathrm{ppm})$ and $\mathrm{C}-4^{\mathrm{II}}$ $(110.96 \mathrm{ppm})$ of the nonreducing end were found in down-field in ${ }^{1} \mathrm{H}$ NMR and ${ }^{13} \mathrm{C}$ NMR spectra, while the nonreducing end $\mathrm{H}-1^{\mathrm{II}}(\alpha)$, reducing end $\mathrm{H}-1^{\mathrm{I}}(\beta)$ and reducing end anomeric carbon $\left(\mathrm{C}-1^{\mathrm{I}}\right)$ of guluronic acid residues appeared at 5.21, 4.87 and $96.04 \mathrm{ppm}$, respec-
Table 1. Selected ESIMS data of alginate-derived oligosaccharides

\begin{tabular}{lllll}
\hline & $\begin{array}{l}\text { Fr I (dp 2) } \\
\text { Parent ion }\end{array}$ & $\begin{array}{l}\text { Fr II (dp 3) } \\
{[\mathrm{M}-\mathrm{H}]^{-1}}\end{array}$ & $\begin{array}{l}\text { Fr III (dp 4) } \\
{[\mathrm{M}-\mathrm{H}]^{-1}}\end{array}$ & $\begin{array}{l}\text { Fr IV (dp 5) } \\
{[\mathrm{M}-2 \mathrm{H}]^{-2}}\end{array}$ \\
\hline$m / \mathrm{M}-2 \mathrm{H}]^{-2}$ \\
\hline$M_{\mathrm{r}}$ (tested) & 351.5 & 527.5 & 351.4 & 439.6 \\
$M_{\mathrm{r}}$ (calcd) & 352.5 & 528.5 & 704.8 & 881.2 \\
\hline
\end{tabular}

tively. Thus, 1 was determined as: 4-deoxy- $\alpha$-L-erythrohex-4-enopyranosyluronate-( $1 \rightarrow 4)$ - $\alpha$-L-gulopyranosyluronate $(\Delta \mathrm{G})$. All ${ }^{1} \mathrm{H}$ and ${ }^{13} \mathrm{C}$ NMR data are listed in Table 2 .

Compounds 2 and 3 were isolated from Fr II in a ratio of nearly $1: 1$, and their ${ }^{1} \mathrm{H}$ and ${ }^{13} \mathrm{C}$ NMR data are listed in Table 3. For compound $\mathbf{2}$, the nonreducing end $\mathrm{H}-4^{\mathrm{III}}$ appeared at $5.69 \mathrm{ppm}$, while the characteristic peaks for homoguluronic acids $\mathrm{H}-1 \mathrm{~s}\left(\mathrm{H}-1^{\mathrm{III}}, \mathrm{H}-1^{\mathrm{II}}, \mathrm{H}-1^{\mathrm{I}}\right)$ appeared at 5.02, 4.85 and $4.72 \mathrm{ppm}$, respectively. All carbon and proton signals from the HMQC spectra (Fig. 2A) of 2 supported the following structure: 4deoxy- $\alpha$-L-erythro-hex-4-enopyranosyluronate)-( $(\rightarrow 4)$ $\alpha$-L-gulopyranosyluronate-( $1 \rightarrow 4)$ - $\alpha$-L-gulopyranosyluronate $(\Delta \mathrm{GG})$. For compound 3 , three $\mathrm{H}-1 \mathrm{~s}(\mathrm{H}-1 \mathrm{G} \beta$ at $4.68 \mathrm{ppm}, \mathrm{H}-1 \Delta$ at $4.94 \mathrm{ppm}$ and $\mathrm{H}-1 \mathrm{M}$ at $4.54 \mathrm{ppm}$ ) and further HMQC spectra assignment (Fig. 2B) gave $\mathbf{3}$ as following: 4-deoxy- $\alpha$-L-erythro-hex-4-enopyranosyluronate-( $1 \rightarrow 4)-\beta$-D-mannopyranosyluronate- $(1 \rightarrow 4)-\alpha-\mathrm{L}-$ gulopyranosyluronate $(\Delta \mathrm{MG})$.

There are four compounds $(\mathbf{4}, \mathbf{5}, \mathbf{6}$ and 7) in Fr III with $\mathbf{6}$ as the major fraction. ESIMS suggested that $\mathrm{Fr}$ III is a tetrasaccharide mixture. From the ${ }^{1} \mathrm{H}-{ }^{1} \mathrm{H}$ COSY, HMBC spectra (Fig. 3A and B), and in comparison with structures $1(\Delta \mathrm{G})$ and $\mathbf{2}(\Delta \mathrm{GG})$, compound 4 was elucidated as a homoguluronic acid having the following

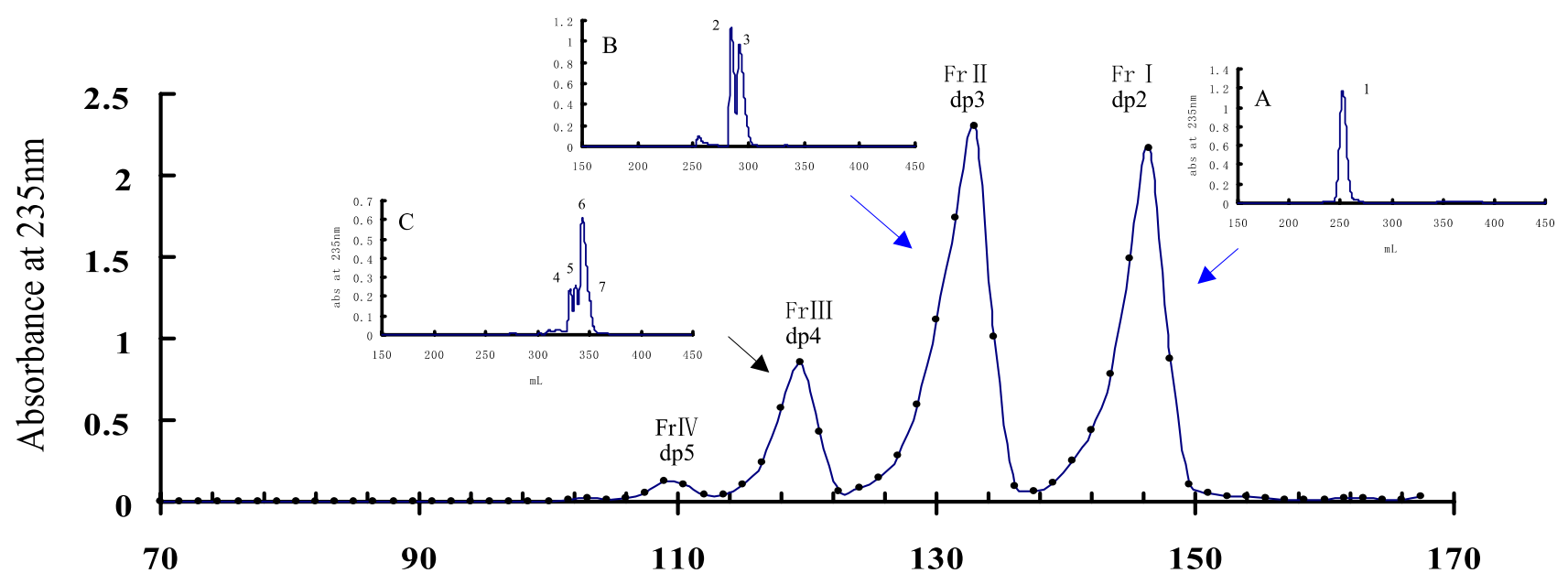

Volume, $\mathrm{mL}$

Figure 1. The separation graph of alginate oligosaccharides on a BioGel P4 column $\left(V_{0}=72 \mathrm{~mL}, V_{\mathrm{t}}=178 \mathrm{~mL}\right)$. Eluted with $0.2 \mathrm{~mol} / \mathrm{L} \mathrm{NH}_{4} \mathrm{HCO}$ at a flow rate of $1.5 \mathrm{~mL} / \mathrm{h}$ with detection at $235 \mathrm{~nm}$. Panel A, B and C was the purification graph of Fr I, Fr II and Fr III, respectively, on SAX-FPLC. The gradient was $0-0.4 \mathrm{~mol} / \mathrm{L} \mathrm{NaCl}(\mathrm{pH} 3.5)$ at $3 \mathrm{~mL} / \mathrm{min}$ for $2.5 \mathrm{~h}$. Numbers $1-7$ correspond to compounds 1-7, respectively. 
Table 2. The NMR data of disaccharide $\mathbf{1}^{\mathrm{a}}$

\begin{tabular}{|c|c|c|c|c|c|c|}
\hline \multirow[t]{2}{*}{ Compound } & \multirow[t]{2}{*}{ Terminals } & \multicolumn{5}{|c|}{${ }^{13} \mathrm{C}$ NMR } \\
\hline & & $\overline{C-1}$ & C-2 & C-3 & C-4 & $C-5$ \\
\hline \multirow[t]{7}{*}{$1 \Delta \mathrm{G}$} & $\mathrm{I}$ & $96.04(93.42)$ & $71.61(69.00)$ & $72.66(70.03)$ & $82.39(79.77)$ & $75.92(73.55)$ \\
\hline & II & $103.20(100.39)$ & $69.73(67.07)$ & $65.21(62.39)$ & $110.96(107.99)$ & $146.99(144.61)$ \\
\hline & & \multicolumn{5}{|c|}{${ }^{1} \mathrm{H}$ NMR } \\
\hline & & $\mathrm{H}-1$ & $\mathrm{H}-2$ & $\mathrm{H}-3$ & $\mathrm{H}-4$ & H-5 \\
\hline & $\mathrm{I}(\alpha)$ & 5.19 & 3.87 & 3.63 & - & - \\
\hline & $\mathrm{I}(\beta)$ & $4.87(4.85)$ & $3.55(3.53)$ & $4.20(4.14)$ & $4.16(4.11)$ & $4.44(4.39)$ \\
\hline & II & $5.21(5.18)$ & $3.92(3.91)$ & $4.32(4.29)$ & $5.92(5.88)$ & - \\
\hline
\end{tabular}

${ }^{\mathrm{a}}$ The chemical shifts in brackets are data of Ref. 10 .

Table 3. The NMR data of trisaccharides $\mathbf{2}$ and $\mathbf{3}^{\mathrm{a}}$

\begin{tabular}{|c|c|c|c|c|c|c|}
\hline \multirow[t]{2}{*}{ Compounds } & \multirow[t]{2}{*}{ Terminals } & \multicolumn{5}{|c|}{${ }^{13} \mathrm{C}$ NMR } \\
\hline & & $\mathrm{C}-1$ & $\mathrm{C}-2$ & $\mathrm{C}-3$ & $\mathrm{C}-4$ & $\mathrm{C}-5$ \\
\hline \multirow[t]{3}{*}{$2 \Delta \mathrm{GG}$} & $\mathrm{I}$ & $93.29(94.52)$ & $69.13(70.41)$ & $70.09(71.25)$ & $80.35(81.50)$ & $73.45(74.67)$ \\
\hline & II & 100.49 (101.99) & 64.85 (65.97) & $68.93(70.11)$ & $79.72(80.90)$ & $67.12(68.32)$ \\
\hline & III & $100.83(101.63)$ & $66.91(68.05)$ & $62.72(63.82)$ & $107.77(108.86)$ & $44.71(145.90)$ \\
\hline \multirow{5}{*}{$3 \Delta \mathrm{MG}$} & I & 93.25 & 68.83 & 70.29 & 80.15 & 73.68 \\
\hline & II & 101.37 & 70.51 & 71.21 & 76.09 & 78.26 \\
\hline & III & 100.13 & 66.69 & 63.67 & 107.52 & 145.18 \\
\hline & & \multicolumn{5}{|c|}{${ }^{1} \mathrm{H}$ NMR } \\
\hline & & $\mathrm{H}-1$ & $\mathrm{H}-2$ & $\mathrm{H}-3$ & $\mathrm{H}-4$ & H-5 \\
\hline \multirow[t]{3}{*}{$2 \Delta \mathrm{GG}$} & I & $4.72(4.78)$ & $3.45(3.50)$ & $3.96(4.00)$ & $3.86(3.91)$ & $4.24(4.30)$ \\
\hline & II & $4.85(4.90)$ & $3.70(3.76)$ & $3.94(4.00)$ & $4.08(4.13)$ & $4.31(4.36)$ \\
\hline & III & $5.02(5.08)$ & $3.75(3.81)$ & $4.24(4.23)$ & $5.69(5.75)$ & - \\
\hline \multirow[t]{3}{*}{$3 \Delta \mathrm{MG}$} & I & 4.68 & 3.53 & 4.15 & 3.94 & 4.21 \\
\hline & II & 4.54 & 3.81 & 3.59 & 3.75 & 3.55 \\
\hline & III & 4.94 & 3.77 & 4.28 & 5.57 & - \\
\hline
\end{tabular}

${ }^{\mathrm{a}}$ The chemical shifts in bracket are data of Ref. 15.

structure: 4-deoxy- $\alpha$-L-erythro-hex-4-enopyranosyluronate-( $(1 \rightarrow 4)-\alpha$-L-gulopyranosyluronate- $(1 \rightarrow 4)$ - $\alpha$-L-gulopyranosyluronate-( $1 \rightarrow 4)$ - $\alpha$-L-gulopyranosyluronate ( $\Delta$ GGG). In the HMBC spectrum of $\Delta$ GGG (Fig. $3 B$ ), the cross-peaks of $\left(\mathrm{H}-1^{\mathrm{IV}}, \mathrm{C}-4^{\mathrm{III}}\right),\left(\mathrm{H}-1^{\mathrm{III}}, \mathrm{C}-4^{\mathrm{II}}\right),\left(\mathrm{C}-1^{\mathrm{I}}, \mathrm{H}-\right.$ $\left.2^{\mathrm{I}}\right),\left(\mathrm{C}-1^{\mathrm{I}}, \mathrm{H}-3^{\mathrm{I}}\right),\left(\mathrm{C}-1^{\mathrm{I}}, \mathrm{H}-5^{\mathrm{I}}\right),\left(\mathrm{C}-1^{\mathrm{I}}, \mathrm{H}-1^{\mathrm{II}}\right)$, combined with the ${ }^{1} \mathrm{H}-{ }^{1} \mathrm{H}$ COSY spectrum (Fig. 3A), facilitated the full assignments of 4 . From the ${ }^{1} \mathrm{H}-{ }^{1} \mathrm{H}$ COSY, HMBC spectra (Fig. 4A and B), and in comparison with the structure of $\mathbf{3}(\Delta \mathrm{MG})$, compound $\mathbf{5}$ was determined as the following tetrasaccharide: 4-deoxy- $\alpha$-L-erythro-hex4-enopyranosyluronate-( $1 \rightarrow 4)-\beta$-D-mannopyranosyluronate-( $(1 \rightarrow 4)$ - $\alpha$-L-gulopyranosyluronate-( $1 \rightarrow 4)$ - $\alpha$-L-gulopyranosyluronate $(\triangle \mathrm{MGG})$. As shown in the HMQC and ${ }^{1} \mathrm{H}-{ }^{1} \mathrm{H}$ COSY spectra (Fig. 4A) of 5, upfield $\mathrm{H}-1^{\mathrm{III}}$ $(4.52 \mathrm{ppm})$ indicates that residue III is a mannuronic acid. In the HMBC spectrum of 5 (Fig. 4B), the crosspeaks between $\mathrm{H}-1^{\mathrm{IV}}(4.92 \mathrm{ppm})$ and $\mathrm{C}-4^{\mathrm{III}}(78.28 \mathrm{ppm})$, $\mathrm{H}-1^{\mathrm{III}}$ and $\mathrm{C}-3^{\mathrm{II}}, \mathrm{H}-1^{\mathrm{II}}$ and $\mathrm{C}-4^{\mathrm{I}}, \mathrm{C}-1^{\mathrm{I}}$ and $\mathrm{H}-2^{\mathrm{I}}, \mathrm{C}-1^{\mathrm{I}}$ and $\mathrm{H}-3^{\mathrm{I}}, \mathrm{C}-1^{\mathrm{I}}$ and $\mathrm{H}-5^{\mathrm{I}}, \mathrm{C}-1^{\mathrm{I}}$ and $\mathrm{H}-1^{\mathrm{II}}, \mathrm{H}-4^{\mathrm{II}}$ and $\mathrm{C}-1^{\mathrm{III}}, \mathrm{H}-$
$4^{\mathrm{I}}$ and $\mathrm{C}-\mathrm{1}^{\mathrm{II}}$ are important correlations that confirm the linkage sequence. Similar NMR spectral analyses of $\mathbf{6}$ and 7 (Table 4, Fig. 5A and B) suggested the following structures: 4-deoxy- $\alpha$-L-erythro-hex-4-enopyranosyluronate-( $1 \rightarrow 4)-\alpha$-L-gulopyranosyluronate- $(1 \rightarrow 4)-\beta$-D-mannopyranosyluronate-( $(1 \rightarrow 4)-\alpha$-L-gulopyranosyluronate $(\Delta \mathrm{GMG}, 6)$ and 4 -deoxy- $\alpha$-L-erythro-hex-4-enopyranosyluronate-( $(\rightarrow 4)$ - $\beta$-D-mannopyranosyluronate- $(1 \rightarrow 4)$ $\beta$-D-mannopyranosyluronate-( $1 \rightarrow 4)$ - $\beta$-D-mannopyranosyluronate $(\triangle \mathrm{MMM}, 7)$.

In this paper, seven oligosaccharides were purified from alginate oligosaccharide mixture, and the yields of compounds 1-7 are $40.2 \%, 23.4 \%, 21.4 \%, 1.9 \%, 2.0 \%$, $7.8 \%$ and $0.8 \%$, respectively. Structural elucidation showed that only one disaccharide $(\Delta \mathrm{G}, 40.2 \%)$ and two trisaccharides $(\Delta \mathrm{GG}, 23.4 \% ; \Delta \mathrm{MG}, 21.4 \%)$ were separated from the mixture. Based on the fact that no $\Delta \mathrm{M}$, $\Delta \mathrm{MM}$ or $\Delta \mathrm{GM}$ fractions were separated from the mixture, we postulated that the hydrolysis mainly occurred between two guluronic acids (- $\mathrm{G}-\mathrm{G}-)$ making one 

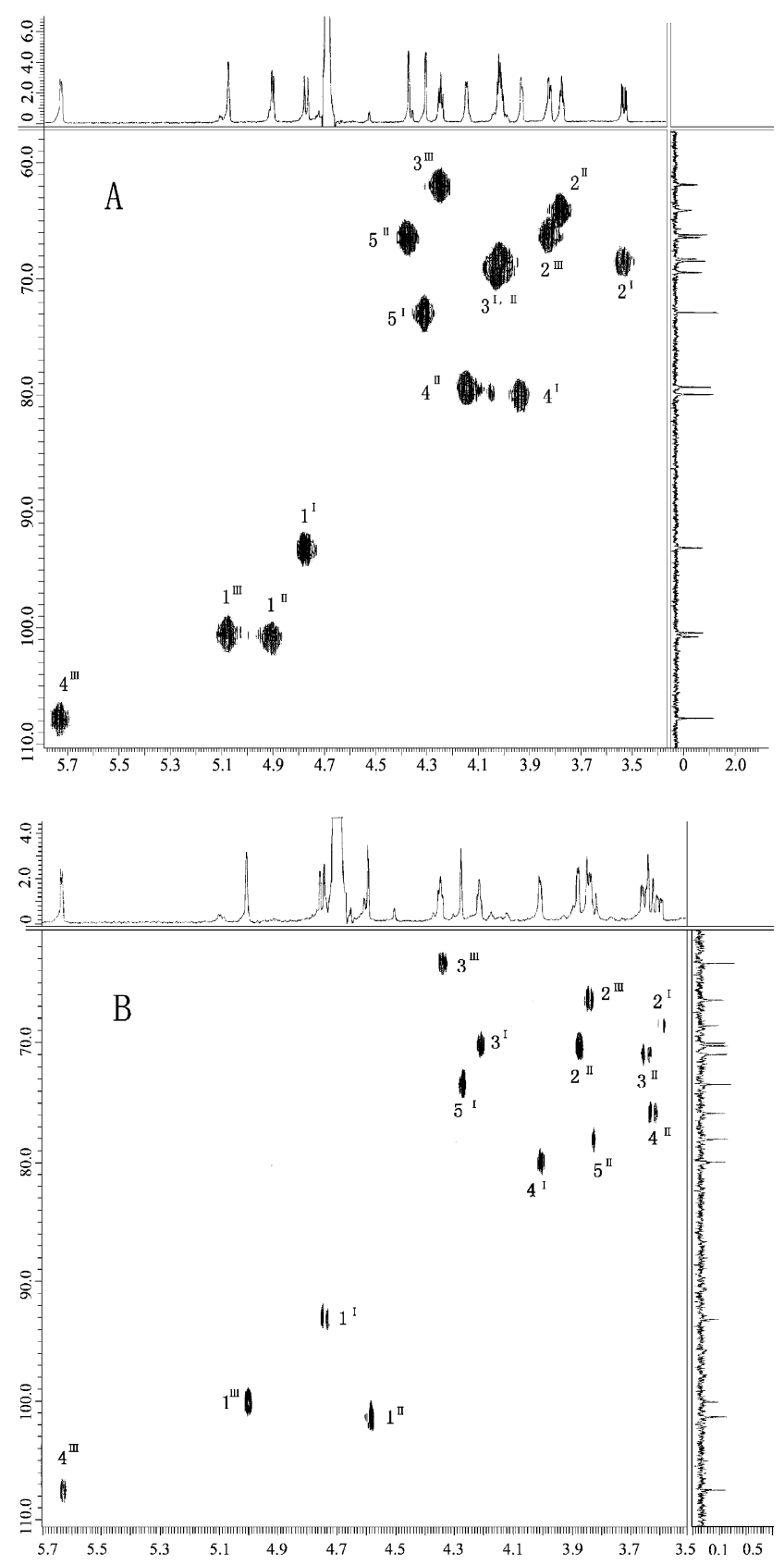

Figure 2. HMQC of trisaccharide 2 (A) and $\mathbf{3}$ (B). I: reducing end, II: middle residues; III: nonreducing end; and the numbers are the positions in pyranosyluronic acids.

guluronic acid $(\mathrm{G})$ residue on the reducing end and an unsaturated guluronic acid $(\Delta)$ in the nonreducing end for all products. These results proved that the alginate lyase, purified from Vibro sp. 510, was $\alpha$-(1 $\rightarrow 4)$-Lguluronic acid lyase. Furthermore, a high content of dito tetrasaccharides $(98 \%)$, a very low yield of pentasaccharide $(1.99 \%)$ and no trace amount of hexasaccharide in the solution, indicated that the minimal recognition oligosaccharide of this enzyme should be one of the following pentasaccharides: GGGGG, GGGMG, MGGMG or GGGMG. The hydrolysis mechanism of
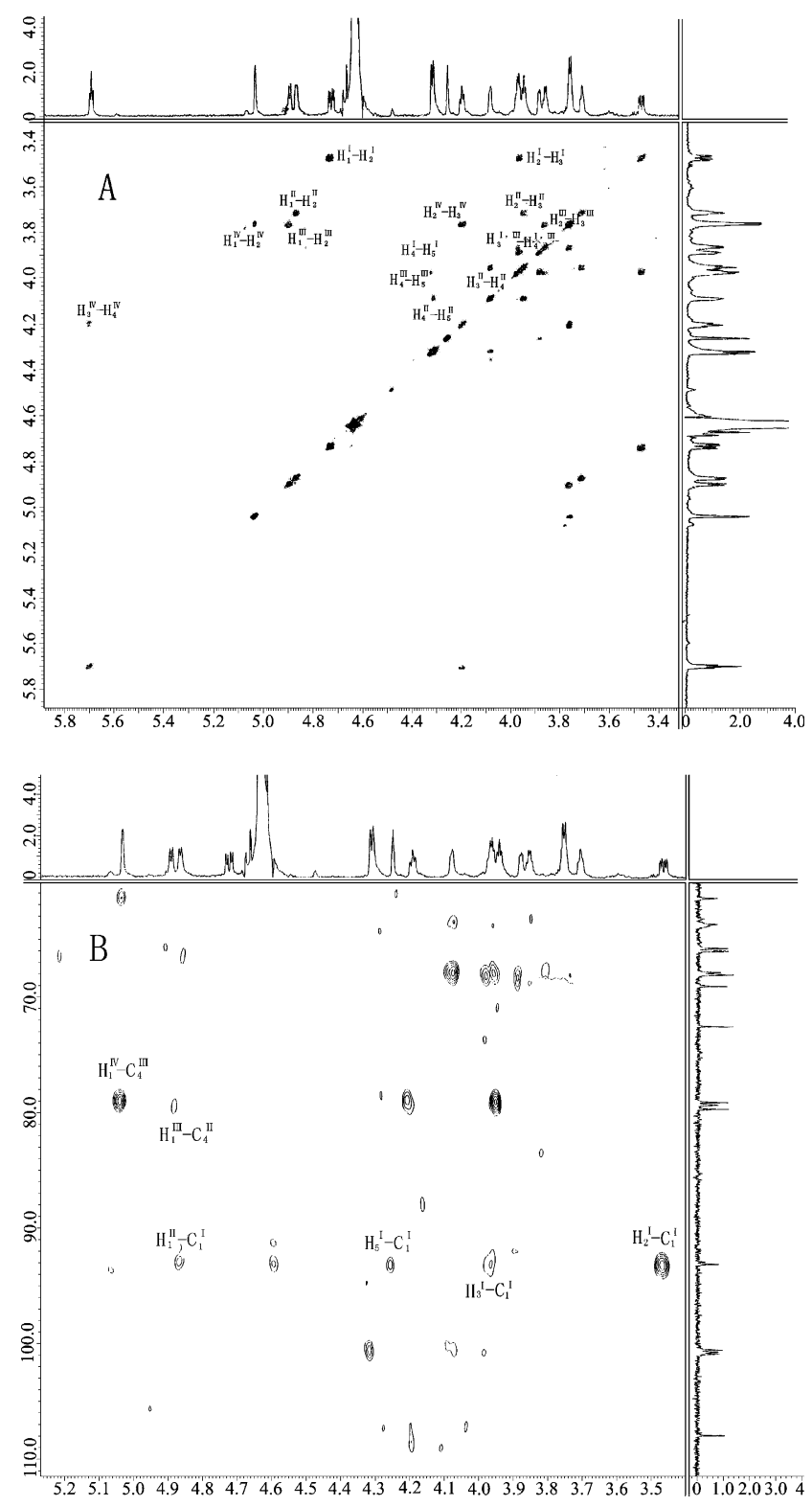

Figure 3. ${ }^{1} \mathrm{H}-{ }^{1} \mathrm{H}$ COSY (A) and $\mathrm{HMBC}(\mathrm{B})$ of tetrasaccharide 4. IV: nonreducing end; III: middle residues near to nonreducing end; II: middle residues near to reducing end; I: reducing end, and the numbers are the positions in pyranosyluronic acids.

this enzyme is illustrated in Figure 6. This result is similar to $\alpha$-L-guluronate lyase purified from Corynebacterium sp. ALY-1. ${ }^{23}$

In conclusion, the alginate was hydrolyzed by alginate lyase of Vibro sp. 510, furnishing oligosaccharide mixtures that were separated on a BioGel P4 column. Each uniform-sized fraction was further purified on a SAXFPLC column, and seven oligosaccharides were obtained, the structures of which were determined by ESIMS and 2D NMR techniques. All of these oligosaccharides will be used as building blocks in the chemical synthesis of neoglycoprotein, neoglycolipid or in the alginate lyase-oligosaccharide crystal studies. ${ }^{24,25}$ 

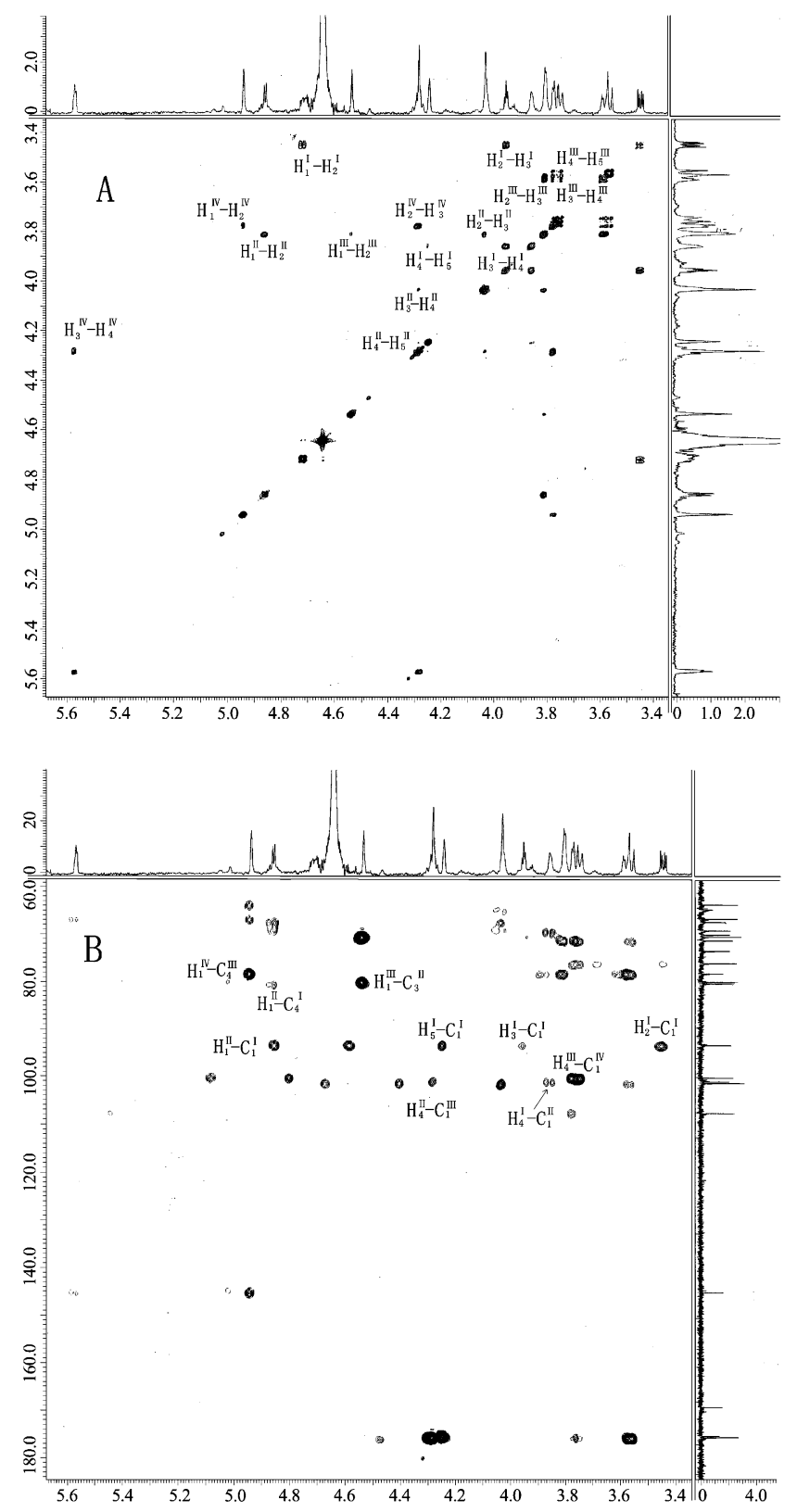

Figure 4. ${ }^{1} \mathrm{H}-{ }^{1} \mathrm{H}$ COSY (A) and $\mathrm{HMBC}(\mathrm{B})$ of tetrasaccharide 5. IV: nonreducing end; III: middle residues near to nonreducing end; II: middle residues near to reducing end; I: reducing end. The numbers are the positions in pyranosyluronic acids.

\section{Experimental}

\subsection{Materials}

Alginate from L. Japonica was purchased from Huahai Pharmaceutical industry (Qingdao, China), and the ratio of $\mathrm{M} / \mathrm{G}$ is 2.28 . BioGel P4 (extra fine, $45 \mu \mathrm{m}$ ) was from BioRad (Richmond, CA). Sephadex G-10 was from Amersham Biosciences (Uppsala, Sweden). SAXFPLC was performed on a Spherisorb S5 SAX
Table 4. The NMR data of tetrasaccharides $4,5,6$ and 7

\begin{tabular}{|c|c|c|c|c|c|c|}
\hline \multirow{2}{*}{$\begin{array}{l}\text { Com- } \\
\text { pounds }\end{array}$} & \multirow[t]{2}{*}{ Terminals } & \multicolumn{5}{|c|}{${ }^{13} \mathrm{C}$ NMR } \\
\hline & & $\mathrm{C}-1$ & $\mathrm{C}-2$ & $\mathrm{C}-3$ & C-4 & C-5 \\
\hline \multirow[t]{4}{*}{$4 \Delta \mathrm{GGG}$} & I & 93.31 & 69.15 & 70.11 & 80.35 & 73.45 \\
\hline & II & 100.69 & 64.89 & 68.95 & 80.02 & 67.16 \\
\hline & III & 100.86 & 65.01 & 69.15 & 79.79 & 67.16 \\
\hline & IV & 100.56 & 66.92 & 62.71 & 107.75 & 144.75 \\
\hline \multirow[t]{4}{*}{$5 \Delta \mathrm{MGG}$} & I & 93.30 & 69.16 & 70.09 & 80.40 & 73.47 \\
\hline & II & 100.93 & 64.79 & 69.16 & 67.34 & 63.68 \\
\hline & III & 101.28 & 70.50 & 71.25 & 78.28 & 76.10 \\
\hline & IV & 100.17 & 64.79 & 67.34 & 107.55 & 145.19 \\
\hline \multirow[t]{4}{*}{$6 \Delta \mathrm{GMG}$} & I & 93.30 & 68.88 & 70.29 & 80.22 & 73.75 \\
\hline & II & 101.34 & 70.93 & 71.46 & 77.37 & 76.08 \\
\hline & III & 99.47 & 64.82 & 69.06 & 79.84 & 67.25 \\
\hline & IV & 100.49 & 71.22 & 62.56 & 107.80 & 144.73 \\
\hline \multirow[t]{6}{*}{$7 \Delta \mathrm{MMM}$} & I & 93.09 & 66.70 & 71.46 & 77.37 & 76.21 \\
\hline & II & 100.17 & 70.18 & 71.22 & 78.16 & 76.21 \\
\hline & III & 101.34 & 71.22 & 71.46 & 78.01 & 76.21 \\
\hline & IV & 100.03 & 66.93 & 63.66 & 107.63 & 145.22 \\
\hline & & \multicolumn{5}{|c|}{${ }^{1} \mathrm{H}$ NMR } \\
\hline & & $\overline{\mathrm{H}-1}$ & $\mathrm{H}-2$ & $\mathrm{H}-3$ & $\mathrm{H}-4$ & $\mathrm{H}-5$ \\
\hline \multirow[t]{4}{*}{$4 \Delta \mathrm{GGG}$} & I & 4.71 & 3.46 & 3.96 & 3.87 & 4.24 \\
\hline & II & 4.86 & 3.70 & 3.93 & 4.07 & 4.30 \\
\hline & III & 4.88 & 3.75 & 3.84 & 3.96 & 4.31 \\
\hline & IV & 5.02 & 3.74 & 4.19 & 5.68 & - \\
\hline \multirow[t]{4}{*}{$5 \Delta \mathrm{MGG}$} & I & 4.69 & 3.43 & 3.94 & 3.85 & 4.23 \\
\hline & II & 4.84 & 3.79 & 4.02 & 4.27 & 4.23 \\
\hline & III & 4.52 & 3.79 & 3.56 & 3.73 & 3.54 \\
\hline & IV & 4.92 & 3.76 & 4.28 & 5.55 & - \\
\hline \multirow[t]{4}{*}{$6 \Delta \mathrm{GMG}$} & I & 4.68 & 3.53 & 4.14 & 3.93 & 4.21 \\
\hline & II & 4.52 & 3.76 & 3.59 & 3.82 & 3.57 \\
\hline & III & 4.83 & 3.69 & 3.91 & 4.06 & 4.61 \\
\hline & IV & 5.02 & 3.74 & 4.17 & 5.69 & - \\
\hline \multirow[t]{4}{*}{$7 \Delta \mathrm{MMM}$} & I & 5.04 & 3.81 & 3.58 & 3.70 & 3.55 \\
\hline & II & 4.48 & 3.84 & 3.59 & 3.73 & 3.55 \\
\hline & III & 4.53 & 3.81 & 3.59 & 3.79 & 3.60 \\
\hline & IV & 4.93 & 3.78 & 4.28 & 5.57 & - \\
\hline
\end{tabular}

$(20 \times 250 \mathrm{~mm})$ column (Clwyd, UK). $\mathrm{D}_{2} \mathrm{O}$ was from Cambridge Isotope Laboratories Inc., and the other reagents are G.R. or A.R.

\subsection{Alginate lyase}

The alginate lyase was purified from the fermentation solution of a marine bacterium (Vibro sp. 510). The activity of the enzyme was measured by monitoring the increase of absorbance at $235 \mathrm{~nm}$ at $28^{\circ} \mathrm{C}$ using a UVvis-PC 2101 spectrometer (equipped with thermostatted cell and enzyme dynamic analysis software, UNICO Company, Shanghai, China) in a $2.8-\mathrm{mL}$ reaction mixture containing $0.2 \%(\mathrm{w} / \mathrm{v})$ sodium alginate, $200 \mathrm{mmol} / \mathrm{L}$ $\mathrm{NaCl}, 50 \mathrm{mmol} / \mathrm{L}$ Tris- $\mathrm{HCl}$ buffer $(\mathrm{pH} 7.5)$ and $0.2 \mathrm{~mL}$ of enzyme solution. One unit of the enzyme activity is defined as the amount of enzyme required to cause an increase of one unit per min of optical density at $235 \mathrm{~nm}$. 

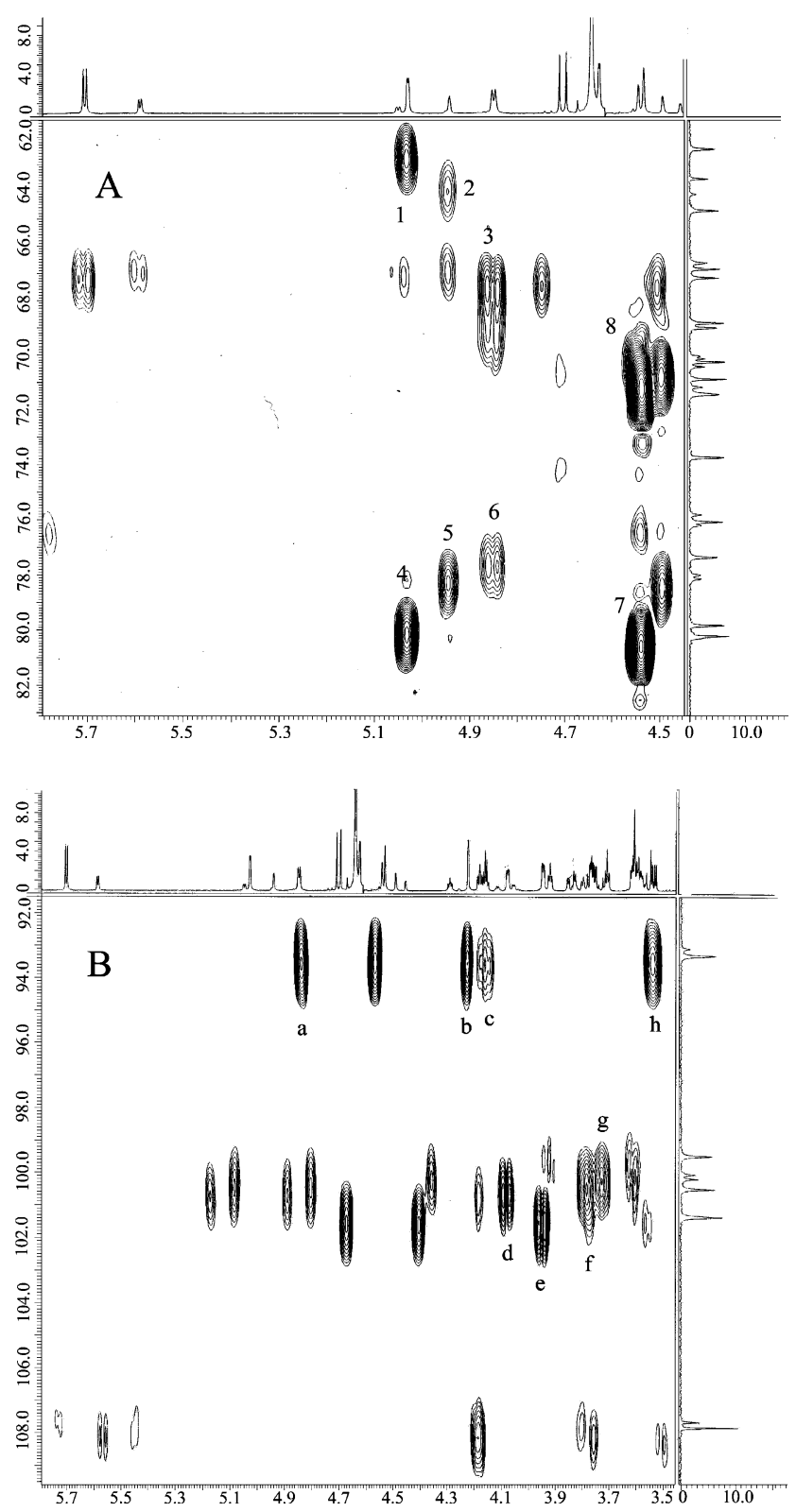

Figure 5. HMBC spectra of tetrasaccharide 6 (A) and 7 (B). The crosspeaks of 6 in panel A are assigned as: $1, \mathrm{H}_{1}^{\mathrm{IV}}-\mathrm{C}_{3}^{\mathrm{IV}} ; 2, \mathrm{H}_{1}^{\mathrm{IV}}-\mathrm{C}_{3}^{\mathrm{IV}} ; 3, \mathrm{H}_{1}^{\mathrm{III}}$ $\mathrm{C}_{5}^{\mathrm{III}} ; 4, \mathrm{H}_{1}^{\mathrm{IV}}-\mathrm{C}_{4}^{\mathrm{III}} ; 5, \mathrm{H}_{1}^{\mathrm{IV}}-\mathrm{C}_{4}^{\mathrm{III}} ; 6, \mathrm{H}_{1}^{\mathrm{III}}-\mathrm{C}_{4}^{\mathrm{II}} ; 7, \mathrm{H}_{1}^{\mathrm{II}}-\mathrm{C}_{4}^{\mathrm{I}} ; 8, \mathrm{H}_{1}^{\mathrm{II}}-\mathrm{C}_{2}^{\mathrm{II}} ; \mathrm{I}$ : reducing end; II: middle residues near to reducing end; III: middle residues near to nonreducing end; IV: nonreducing end. Square brackets stand for contaminates signals of $\triangle M M M$ in $\mathbf{6}$; The crosspeaks of 7 in panel $\mathbf{B}$ are assigned as: a, $\mathrm{H}_{1}^{\mathrm{III}}-\mathrm{C}^{\mathrm{II}}$; b, $\mathrm{H}_{5}^{\mathrm{I}}-\mathrm{C}_{1}^{\mathrm{I}}$; c, $\mathrm{H}_{3}^{\mathrm{I}}-\mathrm{C}_{1}^{\mathrm{I}}$; d, $\mathrm{H}_{4}^{\mathrm{III}}-\mathrm{C}_{1}^{\mathrm{IV}} ; \mathrm{e}, \mathrm{H}_{4}^{\mathrm{I}}-\mathrm{C}_{1}^{\mathrm{II}} ; \mathrm{f}, \mathrm{H}_{4}^{\mathrm{I}}-\mathrm{C}_{1}^{\mathrm{III}} ; \mathrm{g}, \mathrm{H}_{4}^{\mathrm{III}}-\mathrm{C}_{1}^{\mathrm{IV}} ; \mathrm{h}, \mathrm{H}_{2}^{\mathrm{I}}-\mathrm{C}_{1}^{\mathrm{I}}$; I: reducing end; II: middle residues near to reducing end; III: middle residues near to nonreducing end; IV: nonreducing end.

\subsection{Preparation of alginate oligosaccharides}

Alginate $(5 \mathrm{~g})$ was dissolved in $1 \mathrm{~L}$ of $50 \mathrm{mmol} / \mathrm{L}$ Tris$\mathrm{HCl}$ buffer ( $\mathrm{pH} 7.5)$, and 50 units alginate lyase were added. One unit of enzyme activity was defined as the amount of enzyme required to cause an increase of one

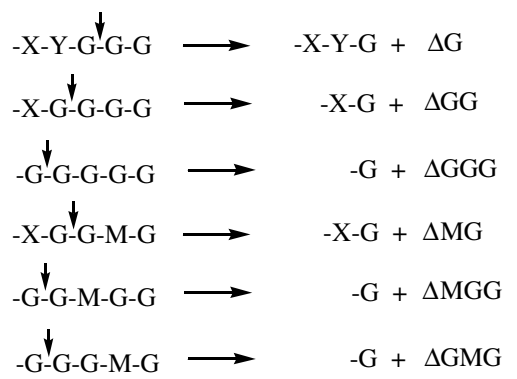

Figure 6. Possible modes for alginate hydrolysis with alginate lyase Vibro sp. 510. $\mathrm{X}=\mathrm{M}$ or $\mathrm{G} ; \mathrm{Y}=\mathrm{G}$ or $\mathrm{M} ; \mathrm{G}$ : guluronic acid; $\mathrm{M}$ : mannuronic acid; $\downarrow$ : hydrolysis sites.

unit of optical density at $235 \mathrm{~nm} . .^{10}$ The reaction was carried out at $28^{\circ} \mathrm{C}$ for $24 \mathrm{~h}$, and then the solution was heated to $100^{\circ} \mathrm{C}$ and kept for $10 \mathrm{~min}$ to stop the hydrolysis reaction. Ethanol was added to the solution until the content of ethanol reached $50 \%(\mathrm{v} / \mathrm{v})$, then the mixture was centrifuged to get rid of the precipitate. The supernatant was collected and evaporated, the solution was filtered though a $0.45-\mu \mathrm{m}$ membrane and lyophilized, and the oligosaccharide mixture was stored at $-20{ }^{\circ} \mathrm{C}$.

\subsection{Low-pressure gel-permeation chromatography}

The alginate oligosaccharides were size-fractioned by low-pressure gel-permeation chromatography (LPGPC). The oligosaccharide mixture $(100-150 \mathrm{mg} / 2 \mathrm{~mL})$ was loaded on BioGel P4 Econo-column $(16 \times 1700 \mathrm{~mm}$, Extra-fine, $45 \mu \mathrm{m}$, BioRad, USA) and eluted with $0.2 \mathrm{~mol} / \mathrm{L} \mathrm{NH}_{4} \mathrm{HCO}_{3}$ solutions at a flow rate of $1.5 \mathrm{~mL} \mathrm{~h}^{-1}$, and the separation was carried out at $\mathrm{rt}$. Each fraction $(1.5 \mathrm{~mL} /$ tube) was gathered using a fraction collector (RediFrac, Pharmacia), and the uronate content was measured at $235 \mathrm{~nm}$.

\subsection{Strong anion-exchange fast-protein liquid chroma- tography (SAX-FPLC)}

The uniform sized fractions that separated from the BioGel P4 column, were further separated on the SAXFPLC system (ÄKTA ${ }^{\mathrm{TM}}$ FPLC equipped with P-920 pumps, conductivity and UV-monitor, and UNICOR ${ }^{\mathrm{TM}}$ V1.11 data processing software). The column was Spherisorb S5 SAX $(20 \times 250 \mathrm{~mm})$, and was eluted with a linear gradient from 0 to $0.4 \mathrm{~mol} / \mathrm{L} \mathrm{NaCl}$ solution at a flow rate of $2 \mathrm{~mL} / \mathrm{min}$ for $2.5 \mathrm{~h}$.

\subsection{Desalting}

Each fraction was rotary evaporated and desalted on a Sephadex G-10 column $(10 \times 1000 \mathrm{~mm})$, eluted with double distilled water. 


\subsection{ESIMS}

Electrospray-ionization mass spectroscopy (TSQ LC/ MS/MS, Finnegan Company) was used for determination of the molecular mass of each oligosaccharide. Positive and negative-ionization modes were used to get the mass spectra at the same time. The sample was dissolved in 1:1 $\mathrm{MeOH}-\mathrm{H}_{2} \mathrm{O}(10 \mathrm{pmol} / \mathrm{mL})$, and it was delivered to the electrospray source using a syringe pump at a flow rate of $5 \mu \mathrm{L} / \mathrm{min}$. The mass scans range was from 100 to 1100 daltons. The capillary temperature was kept at $250{ }^{\circ} \mathrm{C}$, and nitrogen gas was used as nebulizing and desolvation gas.

\subsection{NMR spectroscopy}

The pure samples $(1-5 \mathrm{mg})$ were dissolved in $1 \mathrm{~mL}$ of $\mathrm{D}_{2} \mathrm{O}(99.96 \%)$ and freeze-dried two times to remove exchangeable protons, and then dissolved in $0.5 \mathrm{~mL}$ of $\mathrm{D}_{2} \mathrm{O}(99.96 \%)$ for NMR analysis. All NMR analyses such as ${ }^{1} \mathrm{H},{ }^{13} \mathrm{C}$ NMR, ${ }^{1} \mathrm{H}-{ }^{1} \mathrm{H}$ COSY, HMQC and HMBC were performed on JEOL ECP 600 MHZ spectrometer at $298 \mathrm{~K}$.

\section{Acknowledgements}

This study was supported in part by National Basic Research Program of China (2003CB716400), National Natural Science Foundation of China (Projects 30370345 and 30330690) and National Key Technology R\&D Program of China (2002AA2Z3145).

\section{References}

1. Haug, A.; Larsen, B.; Smidsrod, O. Acta Chem. Scand. 1966, 20, 183-190.

2. Haug, A.; Larsen, B.; Smidsrod, O.; Painter, T. Acta Chem. Scand. 1969, 23, 2955-2962.
3. Ci, S. X.; Huynh, T. H.; Louie, L. W.; Yong, A.; Beals, B. J.; Ron, N.; Tsang, W. G.; Soon-Shiang, P.; Desai, N. P. J. Chromatogr. A 1999, 864, 199-210.

4. Johnson, F. A.; Craig, D. Q.; Mercer, A. D. J. Pharm. Pharmacol. 1997, 49, 639-643.

5. Kawada, A.; Hiura, N.; Shiraiwa, M.; Tajima, S.; Hiruma, M.; Hara, K.; Ishibashi, A.; Takahara, H. FEBS Lett. 1997, 408, 43-46.

6. Natsume, M.; Kamo, Y.; Hirayama, M.; Adachi, T. Carbohydr. Res. 1994, 258, 187-197.

7. Ariyo, B.; Tamerler, C.; Bucke, C.; Keshavarz, T. FEMS Microbiol. Lett. 1998, 166, 165-170.

8. Iwamoto, Y.; Xu, X.; Tamura, T.; Oda, T.; Muramatsu, T. Biosci. Biotechnol. Biochem. 2003, 67, 258-263.

9. Xue, C.; Yu, G.; Hirata, T.; Terao, J.; Lin, H. Biosci. Biotechnol. Biochem. 1998, 62, 206-209.

10. Liu, Y.; Jiang, X.; Liao, W.; Guan, H. J. Chromatogr. A 2002, 968, 71-78.

11. Boyd, J.; Turvey, S. R. Carbohydr. Res. 1977, 57, 163-171.

12. Linker, A.; Evens, L. R. J. Bacteriol. 1984, 159, 958964.

13. Gacesa, P. FEBS Lett. 1987, 212, 199-202.

14. Gacesa, P. Int. J. Biochem. 1992, 24, 545-552.

15. (a) Heyraud, A.; Colin-Morel, P.; Girond, S.; Richard, C.; Kloareg, B. Carbohydr. Res. 1996, 291, 115-126; (b) Heyraud, A.; Gey, C.; Leonard, C.; Rochas, C.; Girond, S.; Kloareg, B. Carbohydr. Res. 1996, 289, 11-23.

16. Liu, Y.; Jiang, X.; Cui, H.; Guan, H. J. Chromatogr. A 2000, 884, 105-111.

17. Quemener, B.; Desire, C.; Debrauwer, L.; Rathahao, E. J. Chromatogr. A 2003, 984, 185-194.

18. Yang, H. O.; Gunay, N. S.; Toida, T.; Kuberan, B.; Yu, G.; Kim, Y. S.; Linhardt, R. J. Glycobiology 2000, 10, 1033-1039.

19. Grasdalen, H.; Larsen, B.; Smidsrod, O. Carbohydr. Res. 1977, 56, 11-15.

20. Grasdalen, H. Carbohydr. Res. 1983, 118, 255-260.

21. Steginsky, C. A.; Beale, J. M.; Floss, H. G.; Mayer, R. M. Carbohydr. Res. 1992, 225, 11-26.

22. Heyraud, A.; Gey, C.; Leonard, C.; Rochas, C.; Girond, S.; Kloareg, B. Carbohydr. Res. 1996, 289, 11-23.

23. Matsubara, Y.; Iwasaki, K.; Muramatsu, T. Biosci. Biotechnol. Biochem. 1998, 62, 1055-1060.

24. Yoon, H. J.; Hashimoto, W.; Miyake, O.; Murata, K.; Mikami, B. J. Mol. Biol. 2001, 307, 9-16.

25. Mishima, Y.; Momma, K.; Hashimoto, W.; Mikami, B.; Murata, K. J. Biol. Chem. 2003, 278, 6552-6559. 